\title{
Evaluation of Indentation Induced Residual Stress on the Surface of Substrate Glasses for Display
}

\author{
Tatsushi NAGAE, Hiromoto KITAHARA, Ken-ichi IKEDA, Fuyuki YOSHIDA, Hideharu NAKASHIMA, \\ Setsurou ITO* and Hiroshi ABE \\ Department of Molecular and Material Sciences, Graduate School of Engineering Sciences, Kyushu University, \\ 6-1, Kasugakouen, Kasuga-shi, Fukuoka 816-8580 \\ *Research Center, Asahi Glass Co., Ltd., 1150, Hazawa-cho, Kanagawa-ku, Yokohama-shi, Kanagawa 221-8755
}

\author{
ディスプレイ用ガラスにおける圧子押し込み誘起表面残留応力の評価 \\ 長江達志·北原弘基 ·池田賢一·吉田冬樹 · 中島英治 ·伊藤節郎* · 阿部 弘 \\ 九州大学大学院総合理工学府物質理工学専攻, 816-8580 福岡県春日市春日公園 6-1 \\ *旭硝子(株)中央研究所, 221-8755 神奈川県横浜市神奈川区羽沢町 1150
}

\begin{abstract}
Residual stress field around a Vickers diamond indentation was studied in three commercial glasses with different strain points $\left(T_{\mathrm{s}}=635^{\circ} \mathrm{C}, 570^{\circ} \mathrm{C}\right.$ and $511^{\circ} \mathrm{C}$, respectively). The basis of the experimental technique is to use cracks from a small indentation as a microprobe to measure the residual stress at a specific point around a large indentation and to study the change of the residual stress by heat treatment. Residual tensile and compressive stresses around a large indentation produced by applying the load of $19.6 \mathrm{~N}$ were distributed up to a distance of about $400 \mu \mathrm{m}$ from the indentation center. For all specimens, the tensile and compressive stresses were about $10 \mathrm{MPa}$ and $-50 \mathrm{MPa} \sim-30 \mathrm{MPa}$, respectively, at a distance of $200 \mu \mathrm{m}$ from the indentation center. The residual stresses decreased by heat treatment at temperatures as low as $300^{\circ} \mathrm{C}$ below the strain point and became zero by keeping the indented specimen at temperatures close to the strain point of each glass, for $7.2 \mathrm{ks}$. The resistance to decrease in residual stresses against temperature was in the order $\mathrm{Si}-\mathrm{B}-\mathrm{Al}-\mathrm{O}\left(\boldsymbol{T}_{\mathrm{s}}=635^{\circ} \mathrm{C}\right)>\mathrm{Si}-\mathrm{Al}-\mathrm{O}\left(T_{\mathrm{s}}=570^{\circ} \mathrm{C}\right)>\mathrm{Si}-\mathrm{Ca}-\mathrm{Na}-\mathrm{O}\left(T_{\mathrm{s}}=511^{\circ} \mathrm{C}\right)$ glass. The results were discussed based on the difference of the mobility of constituent ions and flow of glasses.
\end{abstract}

[Received May 2, 2002; Accepted June 18, 2002]

Key-words : Display glass, Vickers indentation, Residual stress, Molecular dynamics

\section{Introduction}

Glass has excellent optical, mechanical and chemical properties and has been used in a variety of applications. In recent years, the area of application has been expanded to that of electronics and the requirement for properties of glass has been well pronounced.1),2)

Glass which is used for liquid crystal display or plasma display is subjected to fairly high temperature during manufacturing and a micron level distortion affects the dimensional accuracy, hence the quality of products. It is useful to measure the temperature dependence of the reduction of residual stress and to evaluate the heat resistance of various glasses. Extensive studies have been carried out of the measurement of residual stresses based on various techniques. ${ }^{3)-13)}$ With regard to the thin film, coated on a substrate, a technique to measure the distortion of the thin film-substrate composite has been used. Uchida recently reported an analytical technique to determine residual stress in thin film by asymmetric X-ray diffraction. ${ }^{9)}$ Zimmerman reported a computer simulation analysis to estimate the residual stress and stress distribution in glass. ${ }^{11)}$ Bistrad used a ball indentation method to study the residual stress in glass. ${ }^{12)}$ Zeng developed an indentation technique ${ }^{7), 8)}$ to measure the residual stress field around Vickers indentations.

In the present study, Vickers indentation technique ${ }^{7), 8), 13)}$ was applied to evaluate the change of residual stress field; the creation of stress field by an indentation and reduction by subsequent heat treatment. The rise and fall of the residual stress in the surface of glasses with different strain points were discussed based on experimental results and the results of computer simulation by molecular dynamics.

\section{Experimental procedure}

Experiments were made using three glasses with different strain points. They were a $\mathrm{Si}-\mathrm{Ca}-\mathrm{Na}-\mathrm{O}$ system glass ( $5 \mathrm{~mm}$ in thickness), Si-Al-O system glass (3 mm in thickness) and $\mathrm{Si}-\mathrm{B}-\mathrm{Al}-\mathrm{O}$ system glass (1 $\mathrm{mm}$ in thickness) for display. Properties of glasses are shown in Table 1 and glass compositions are shown in Table 2. Vickers diamond indentation experiments were carried out at room temperature $\left(20-24^{\circ} \mathrm{C}\right.$, with $27-52 \%$ humidity) with Akashi AVK Hardness Tester. The primary indentation was made in the surface of each glass with a load of $19.6 \mathrm{~N}$. The second indentation was made with a load of $4.9 \mathrm{~N}$. In each indentation, the load was applied for $15 \mathrm{~s}$. The second indentation was oriented so that the cracks form in the radial and tangential directions relative to the primary indentation. Introduction of the second indentation will affect the stress field created by the primary indentation. Therefore the load to make the second indentation should be small so that the effect on the stress field created by the primary indentation can be minimized. The length of the cracks from the second indentation in the radial and tangential directions with regard to the primary indentation was measured $15 \mathrm{~s}$ after the indentation on a TV monitor which was connected to the Hardness Tester. The center-to-center distance between the two indentations was also measured on the screen. The sequence of indentation experiments was repeated at positions of different center-to-center distance. The length of the cracks from the second indentation was measured and the tensile and compressive residual stresses were calculated.

The heat treatment was carried out in an electric furnace after the primary indentation. The glass specimen was heat- 
Table 1. Properties of Glasses

\begin{tabular}{cccccc}
\hline Sample & $\begin{array}{c}\text { Strain point } \\
/{ }^{\circ} \mathrm{C}\end{array}$ & $\begin{array}{c}\text { Young's modulus } \\
/ \mathrm{GPa}\end{array}$ & $\begin{array}{c}\text { Density } \\
/ 10^{3} \mathrm{~kg} \cdot \mathrm{m}^{-3}\end{array}$ & $\begin{array}{c}\text { Thermal expansion coefficient } \\
/ \mathrm{C}^{-1}\end{array}$ & $\begin{array}{c}\text { Fracture toughness } \\
/ \mathrm{MPa} \cdot \mathrm{m}^{1 / 2}\end{array}$ \\
\hline Si-Ca-Na-O system glass & 511 & 72 & 2.49 & $87 \times 10^{-7}$ & 0.75 \\
Si-Al-O system glass & 570 & 76 & 2.77 & $83 \times 10^{-7}$ & 0.64 \\
Si-B-Al-O system glass & 635 & 73 & 2.77 & $49 \times 10^{-7}$ & 0.78 \\
\hline
\end{tabular}

Table 2. Glass Composition

\begin{tabular}{cc}
\hline Sample & Composition $/ \mathrm{mol} \%$ \\
\hline Si-Ca-Na-O system glass & $13(\mathrm{Na}, \mathrm{K})_{2} \mathrm{O}-14(\mathrm{Mg}, \mathrm{Ca}) \mathrm{O}-1 \mathrm{Al}_{2} \mathrm{O}_{3}-72 \mathrm{SiO}_{2}$ \\
Si-Al-O system glass & $9(\mathrm{Na}, \mathrm{K})_{2} \mathrm{O}-18(\mathrm{Mg}, \mathrm{Ca}, \mathrm{Sr}, \mathrm{Ba}) \mathrm{O}-5 \mathrm{Al}_{2} \mathrm{O}_{3}-66 \mathrm{SiO}_{2}-2 \mathrm{ZrO}_{2}$ \\
Si-B-Al-O system glass & $19(\mathrm{Mg}, \mathrm{Ca}, \mathrm{Sr}, \mathrm{Ba}) \mathrm{O}-14\left(\mathrm{~B}, \mathrm{Al}_{2} \mathrm{O}_{3}-67 \mathrm{SiO}_{2}\right.$ \\
\hline
\end{tabular}
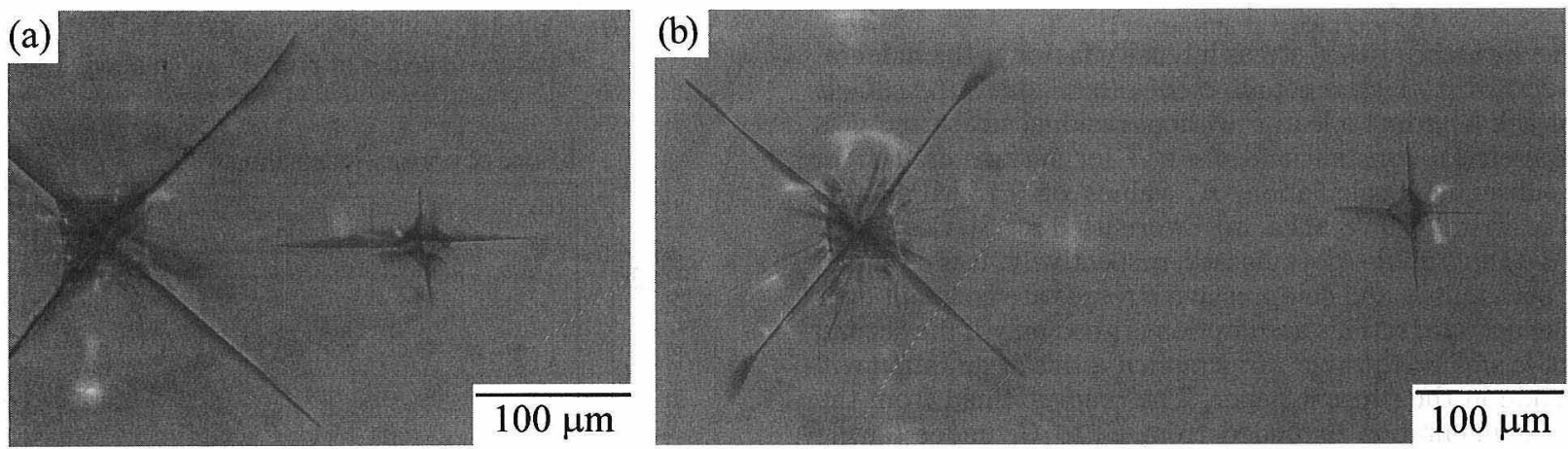

Fig. 1. Optical micrograph of indentations on (a) Si-Al-O system glass; as-indented, near distance, (b) Si-Al-O system glass; as-indented, far distance.

ed at various temperatures between $200^{\circ} \mathrm{C}$ and $700^{\circ} \mathrm{C}$ for 7.2 $\mathrm{ks}$ in air. The specimen was cooled to room temperature and the second indentation was made. Crack length was measured and the residual stress was calculated in the same way as was adopted in the as-indented specimen. The indentation profiles were characterized with a DEKTAK3 Version 2.01a/J profilometer and KEYENCE Color Laser 3D Profile Microscope VK-8500 instruments for as-indented and heattreated specimens.

Molecular dynamics simulation was carried out for three glass samples with Fujitsu WinMASPHYC Pro by using Kawamura potential as an interatomic potential. Ions constituting glass samples were distributed, in compliance with molar fraction, in virtual tetragonal lattice using random number selection. Stabilized simulations of ionic positions were repeated for 10000 times, at ten femto second $\left(10^{-15} \mathrm{~s}\right)$ intervals and $2000^{\circ} \mathrm{C}$ under the ambient pressure. The glass structure, cooled at a speed of $2 \times 10^{14^{\circ}} \mathrm{C} \cdot \mathrm{s}^{-1}$, was defined as initial structure. Stable ionic positions at desired temperatures were calculated by keeping the glass at each temperature for ten pico second $\left(10^{-11} \mathrm{~s}\right)$. The numbers of ions in a three dimensional lattice was kept constant in the simulation.

\section{Results and discussion}

\subsection{Crack profiles under residual stress}

Figures 1 (a) and (b) show examples of crack patterns of second indentations made under the influence of the primary large indentation for $\mathrm{Si}-\mathrm{Al}-\mathrm{O}$ system glass. Figure 1 (a) shows that in the area near the primary indentation, there is a tangential tensile stress which propagates the crack in the radial direction. A compressive stress is developed in the

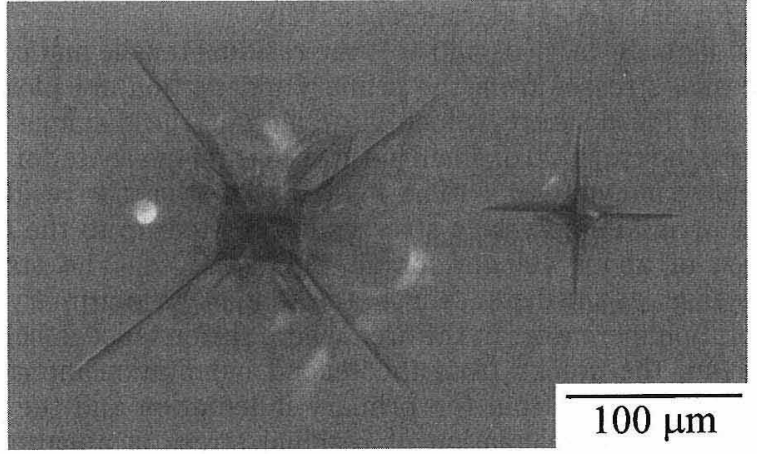

Fig. 2. Optical micrograph of indentations on Si-Al-O system glass; after heat treatment at $600^{\circ} \mathrm{C}$

radial direction and the length of cracks in the tangential direction decreases. Figure 1 (b) shows that at a far distance from the primary indentation, the influence of the residual stress diminishes to zero and the second indentation behaves as a normal indentation.

Figure 2 gives an example of crack patterns of second indentation located close to the primary indentation which had been heat-treated at $600^{\circ} \mathrm{C}$ for $7.2 \mathrm{ks}$ before the second indentation was made. No or little influence of the residual compressive and tensile stresses from the primary indentation could be observed and the second indentation behaved as a normal indentation. In case when the crack formed from a second indentation comes close to the crack from a 
primary indentation, the former crack sometime extended to the latter; similar behavior as was reported by Lardner and Malou. ${ }^{14), 15)}$ When such behavior is observed, data were judged invalid.

\subsection{As-indented residual stress}

By measuring the second crack length, it is possible to calculate the residual stress field around the primary indentation. In order to calculate the residual stress around an indentation, fracture mechanics analysis has been proposed by Zeng.7) The residual stresses were calculated by using the following equations.

$$
\begin{aligned}
& \sigma_{\mathrm{r}}=K_{\mathrm{c}} \frac{1-\left(C_{0} / C_{1}\right)^{3 / 2}}{\Phi C_{1}^{1 / 2}} ; \text { for tensile residual stress } \\
& \sigma_{\mathrm{c}}=-K_{\mathrm{c}} \frac{1-\left(C_{0} / C_{2}\right)^{3 / 2}}{\Phi C_{2}^{1 / 2}} ; \text { for compressive residual } \\
& \text { stress }
\end{aligned}
$$

where $K_{\mathrm{c}}$ is the critical stress intensity factor at the indentation crack tip which is not affected with residual stress, $C_{0}$ is the crack length at a load $P$ without residual stress and $\Phi$ is a geometrical constant and $\Phi=\pi^{1 / 2}$ for surface cracks. In the subsequent calculation, $K_{\mathrm{c}}$ values of $0.75 \mathrm{MPa} \cdot \mathrm{m}^{1 / 2}$, $0.64 \mathrm{MPa} \cdot \mathrm{m}^{1 / 2}, 0.78 \mathrm{MPa} \cdot \mathrm{m}^{1 / 2}$ were used for $\mathrm{Si}-\mathrm{Ca}-\mathrm{Na}-\mathrm{O}$, $\mathrm{Si}-\mathrm{Al}-\mathrm{O}$ and $\mathrm{Si}-\mathrm{B}-\mathrm{Al}-\mathrm{O}$ glasses, respectively. It is assumed that both tensile and compressive stresses are constant over the second crack. This assumption is good only if the second crack is small. However, for simplicity, this assumption will be made in the present paper. The crack formed from the second indentation extended from $C_{0}$ to $C_{1}$ under tensile residual stress $\sigma_{\mathrm{r}}$ from the primary indentation. While the crack length decreased from $C_{0}$ to $C_{2}$ under compressive residual stress $\sigma_{\mathrm{c}}$. The crack length $C_{0}$ of each glass was $51.6 \mu \mathrm{m}$ with standard deviation of $1.4 \mu \mathrm{m}$ for $\mathrm{Si}-\mathrm{Ca}-\mathrm{Na}-\mathrm{O}$ glass, $61.3 \mu \mathrm{m}$ with standard deviation of $1.1 \mu \mathrm{m}$ for $\mathrm{Si}-\mathrm{Al}-\mathrm{O}$ glass and $50.1 \mu \mathrm{m}$ with standard deviation of 0.8 $\mu \mathrm{m}$ for $\mathrm{Si}-\mathrm{B}-\mathrm{Al}-\mathrm{O}$ glass, respectively.

In Figs. 3-(a), (b) and (c), the residual tensile and compressive stresses from the primary indentation are plotted against the distance, which is defined as the distance between the crack tip of small indentation and the center of the primary indentation. ${ }^{13)}$ The figures show that the residual tensile and compressive stresses distributed up to the distance of about $400 \mu \mathrm{m}$ for all three glasses. The stress decreases as the distance from the center of the primary indentation increases. In the area where the distance is below $150 \mu \mathrm{m}$, the cracks from the second indentation interfere with the cracks from the primary indentation and the accuracy of the calculation of residual stress is apparently affected. It was a general trend that the compressive stress was larger than the tensile stress; at the distance of $200 \mu \mathrm{m}$, the compressive stress was about $-50 \mathrm{MPa} \sim-30 \mathrm{MPa}$ while the tensile stress was about $10 \mathrm{MPa}$.

3.3 Residual stress after heat treatment

Figure 4 gives residual tensile and compressive stresses from the primary indentation after heat treatment at $500^{\circ} \mathrm{C}$ for $7.2 \mathrm{ks}$. As for $\mathrm{Si}-\mathrm{Ca}-\mathrm{Na}-\mathrm{O}$ glass, with the strain point of $511^{\circ} \mathrm{C}$, the residual stress was reduced to zero, while the residual stress still remained in $\mathrm{Si}-\mathrm{Al}-\mathrm{O}$ system glass with the strain point of $570^{\circ} \mathrm{C}$ after the heat treatment. In Fig. 5, the average residual compressive stress at the distance of $200 \mu \mathrm{m}$ is plotted for $\mathrm{Si}-\mathrm{Al}-\mathrm{O}$ system glass, after heat treatment at various temperatures for $7.2 \mathrm{ks}$. The change of the depth of primary indentation measured with a Laser 3D Profile Microscope is also shown in the figure. Both the residual stress and the depth of the indentation decreased with the increase in temperature. Similar curves were also observed for $\mathrm{Si}-\mathrm{Ca}-\mathrm{Na}-\mathrm{O}$ and $\mathrm{Si}-\mathrm{B}-\mathrm{Al}-\mathrm{O}$ glasses. Curves in Fig. 5
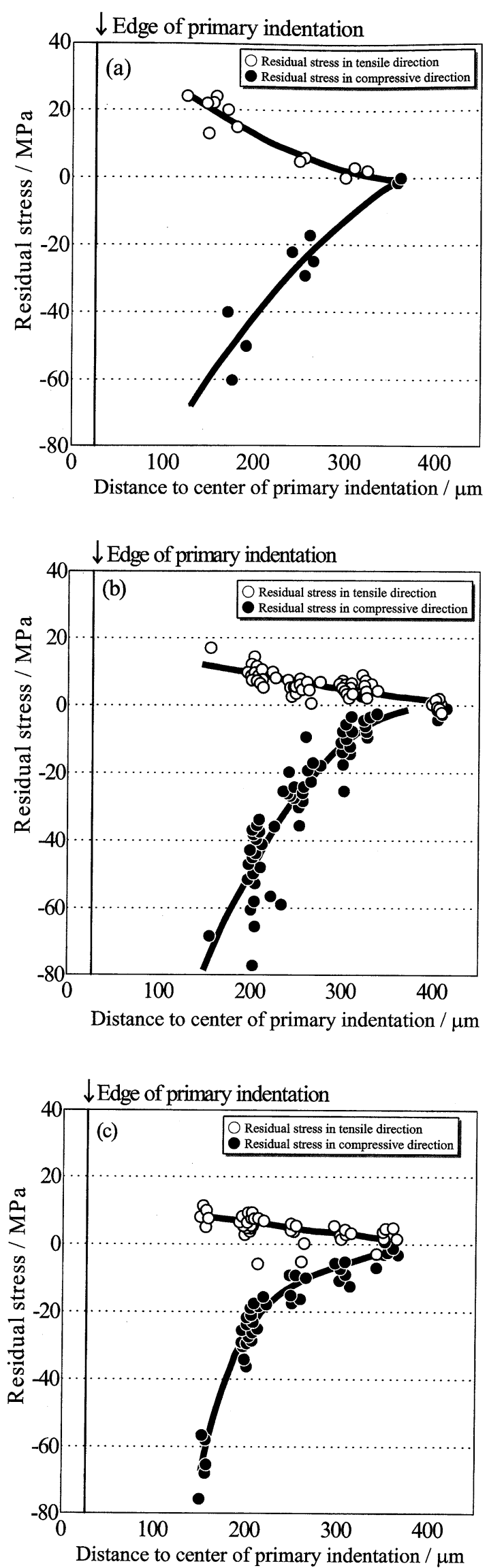

Fig. 3. Residual stress around a $19.6 \mathrm{~N}$ indentation in the surface of (a) a $\mathrm{Si}-\mathrm{Ca}-\mathrm{Na}-\mathrm{O}$ system glass, (b) a $\mathrm{Si}-\mathrm{Al}-\mathrm{O}$ system glass, (c) a $\mathrm{Si}-\mathrm{B}-\mathrm{Al}-\mathrm{O}$ system glass; as-indented. 


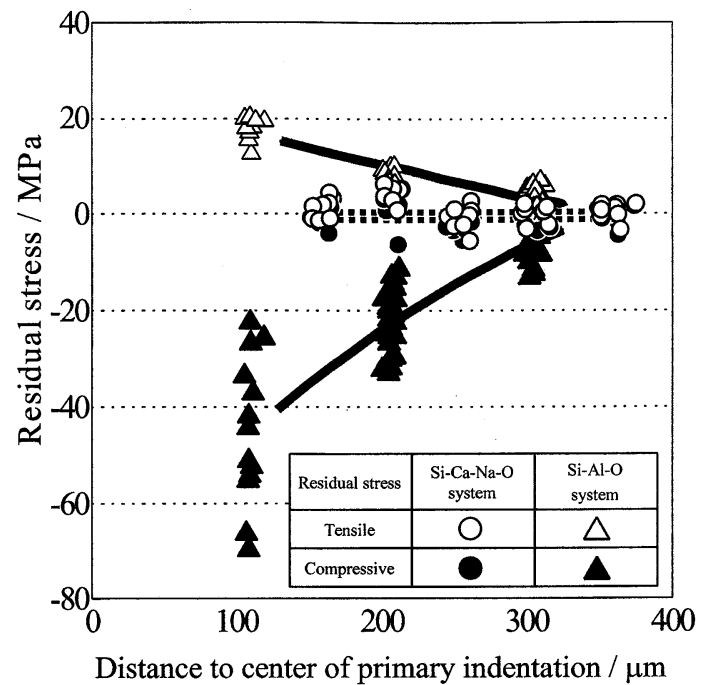

Fig. 4. Residual stress around a $19.6 \mathrm{~N}$ indentation; $500^{\circ} \mathrm{C}, 7.2 \mathrm{ks}-$ heated:

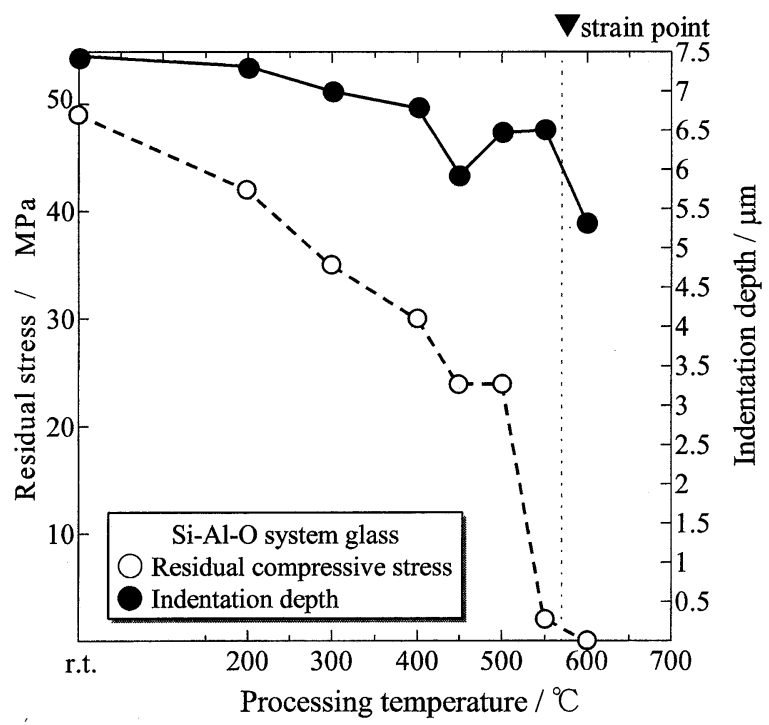

Fig. 5. Residual compressive stress at the distance of $200 \mu \mathrm{m}$ and indentation depth after heat treatment at various temperatures.

show that the residual stress and the indentation depth decrease by heat treatment at the temperatures far below the strain point. In Fig. 6, similar plots of the change of the residual compressive stress are summarized for all three glasses. In Fig. 7, the same data as were shown in Fig. 6 are replotted against normalized stresses; residual stress after heat treatment/as-indented residual stress. It was a common trend that the residual stress decreased at the heating temperature as low as $200^{\circ} \mathrm{C}$ and became zero at the temperatures close to the strain point of each glass.

The basic mechanism for the creation of indenter induced residual stress was discussed by Anstis ${ }^{16)}$ whose analysis is based on a model in which the elastic/plastic field beneath the indenter is resolved into elastic and residual component. ${ }^{17)}$ The radially expanded plastic zone, ${ }^{18)}$ after unloading, exerts a hydrostatic pressure across the outerboundary of the plastic zone hence causing a tangential elastic tensile stress and a radial elastic compressive stress outside the

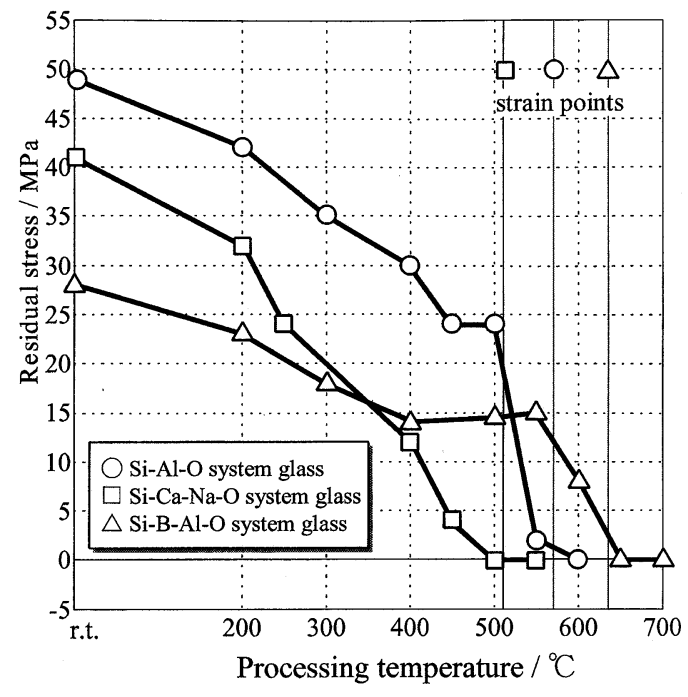

Fig. 6. Residual compressive stress at points $200 \mu \mathrm{m}$ to the center of primary indentation.

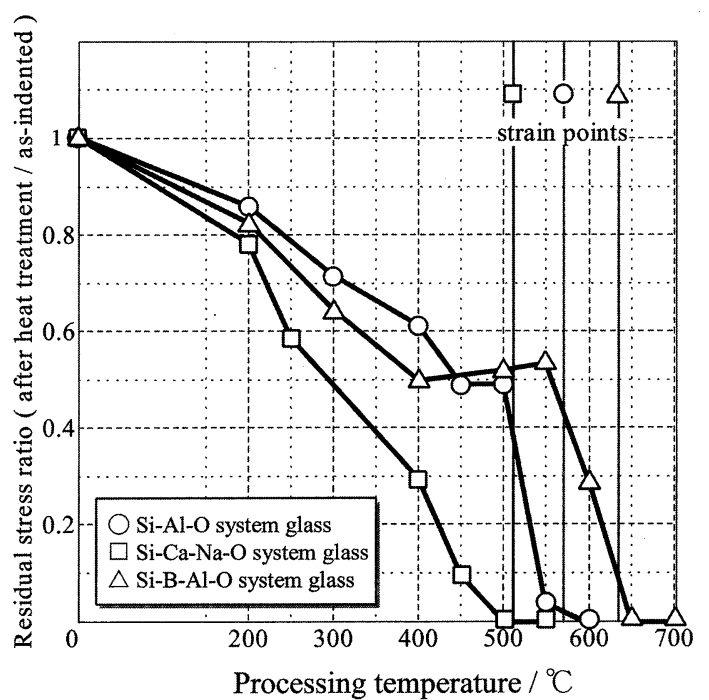

Fig. 7. Residual compressive stress at points $200 \mu \mathrm{m}$ to the center of primary indentation.

boundary. The residual stress is detected and calculated by measuring the crack length of the second indentation as was described in this study.

Approximate pressure beneath the indenter is estimated to be as high as the hardness value of the specimen, $5.3 \mathrm{GPa}$ for $\mathrm{Si}-\mathrm{Ca}-\mathrm{Na}-\mathrm{O}$ system glass. ${ }^{19)}$ The pressure causes plastic zone which created a residual elastic stress field extending to as far as $400 \mu \mathrm{m}$. The heat treatment reduced the residual stress to zero at temperatures close to the strain points.

With regard to the relationship between the change of the residual stress by heat treatment and the properties of glasses, overall trend of the resistance to the decrease of the residual stress against temperature is in the order of $\mathrm{Si}-\mathrm{B}-\mathrm{Al}-\mathrm{O}\left(T_{\mathrm{s}}=635^{\circ} \mathrm{C}\right)>\mathrm{Si}-\mathrm{Al}-\mathrm{O} \quad\left(T_{\mathrm{s}}=570^{\circ} \mathrm{C}\right)>\mathrm{Si}-\mathrm{Ca}-$ $\mathrm{Na}-\mathrm{O}\left(T_{\mathrm{s}}=511^{\circ} \mathrm{C}\right)$ glasses, with some concession due to the scatter of the original data shown in Figs. 3 and 4. The shape of the curves in Fig. 7 suggests that the residual stress in $\mathrm{Si}-\mathrm{Ca}-\mathrm{Na}-\mathrm{O}$ glass decreases relatively monotoni- 


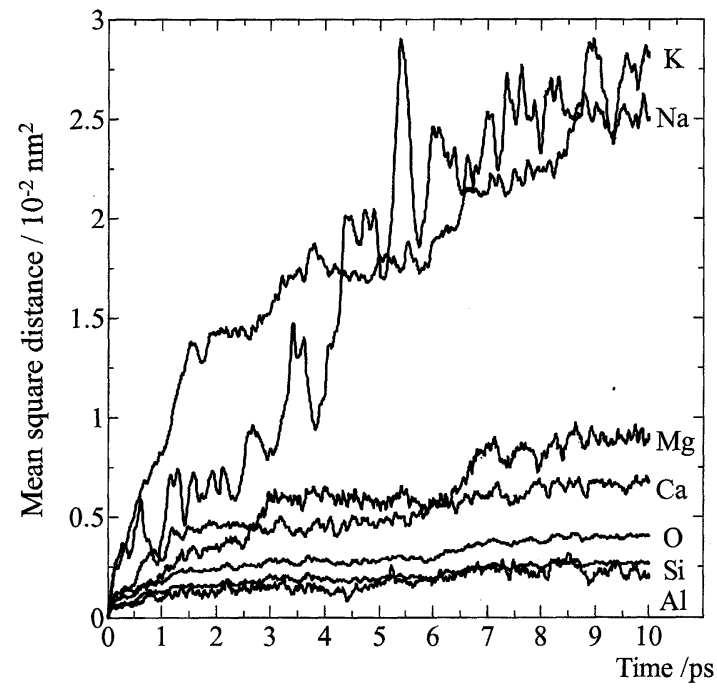

Fig. 8. Estimated mean square distance of ions of a $\mathrm{Si}-\mathrm{Ca}-\mathrm{Na}-\mathrm{O}$ system glass held at $400^{\circ} \mathrm{C}$ for ten pico seconds.

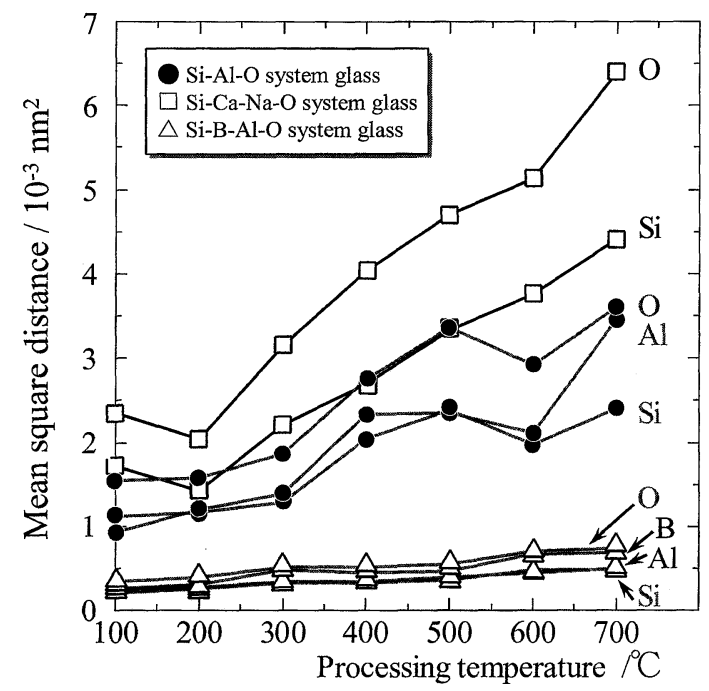

Fig. 9. Estimated mean square distance of network former and oxygen ions held at each temperature for ten pico seconds.

cally with the increase in temperature. On the other hand, the curves for $\mathrm{Si}-\mathrm{B}-\mathrm{Al}-\mathrm{O}$ and $\mathrm{Si}-\mathrm{Al}-\mathrm{O}$ system glasses seem to have plateaus at the temperatures 100 to $200^{\circ} \mathrm{C}$ below the strain points. The decrease in the residual stress at relatively low temperatures could have been caused by the diffusion of ions; probably enhanced by the high mobility of alkali ions. The electric resistivities at $150^{\circ} \mathrm{C}$ are $8.5,12$ and $>15$ $\log \mathrm{ohm} \cdot \mathrm{cm}^{-1}$ for $\mathrm{Si}-\mathrm{Ca}-\mathrm{Na}-\mathrm{O}\left((\mathrm{Na}, \mathrm{K})_{2} \mathrm{O}\right.$ content $=13$ $\mathrm{mol} \%), \mathrm{Si}-\mathrm{Al}-\mathrm{O}\left((\mathrm{Na}, \mathrm{K})_{2} \mathrm{O}\right.$ content $\left.=9 \mathrm{~mol} \%\right)$ and $\mathrm{Si}-\mathrm{B}-$ Al-O (No alkali, Alkaline earth oxide content $=19 \mathrm{~mol} \%$ ) system glasses, respectively.*

The results of molecular dynamics simulation are given in Figs. 8 and 9. Figure 8 shows the relationship of time (pico second) and mean square distance $\left(\mathrm{nm}^{2}\right)$ from the original location of ions in $\mathrm{Si}-\mathrm{Ca}-\mathrm{Na}-\mathrm{O}$ glass kept at $400^{\circ} \mathrm{C}$. Owing to the limitation of short time and diffusion distance of each ion, it is not clear whether the mean square distance and

*Data Sheet, Asahi Glass Co., Ltd. time have the diffusion controlled proportional relationship or not. However, general trend of the results of similar calculation for $\mathrm{Si}-\mathrm{Ca}-\mathrm{Na}-\mathrm{O}, \mathrm{Si}-\mathrm{Al}-\mathrm{O}$ and $\mathrm{Si}-\mathrm{B}-\mathrm{Al}-\mathrm{O}$ system glasses showed that alkali ions ; $\mathrm{Na}$ and $\mathrm{K}$ are high mobility ions while network formers; $\mathrm{Si}, \mathrm{Al}$ and $\mathrm{B}$, are low mobility ions. The mobility of alkali earth ions is generally lower than that of alkali ions and higher than that of network formers. As for the effect of the mobility of ions on the reduction of residual stress by heat treatment, the diffusion of the network formers are considered to play more important role than that of modifiers. Figure 9 plots the mean square distance $\left(\mathrm{nm}^{2}\right)$ of network former and oxygen ions from the original location in each glass kept at different temperatures for 10 pico seconds. Although there are fractuations in the mean square distance vs. temperature curves, overall trend of the mobility of network former and oxygen ions is in the order of $\mathrm{Si}-\mathrm{B}-\mathrm{Al}-\mathrm{O}<\mathrm{Si}-\mathrm{Al}-\mathrm{O}<\mathrm{Si}-\mathrm{Ca}-\mathrm{Na}-\mathrm{O}$ glasses.

It is probable that the high mobility of alkali ions in $\mathrm{Si}-\mathrm{Ca}-\mathrm{Na}-\mathrm{O}$ glass enhanced the mobility of network formers, hence reduced the residual stress by heat treatment monotonically. In the region where temperatures are somewhat below the strain point of $\mathrm{Si}-\mathrm{B}-\mathrm{Al}-\mathrm{O}$ glass, in which no high mobility alkali ion is contained, the diffusion may not have been sufficient to reduce the residual stress to zero, and a plateau is observed in the residual stress curve. After this transition zone, flow becomes eminent near the strain point hence reduces the residual stress to zero. The results of $\mathrm{MD}$ simulation of $\mathrm{Si}-\mathrm{B}-\mathrm{Al}-\mathrm{O}$ glass show that there is no specific change in the mobility of network formers below and above the strain point temperature. It is presumed that the fact that the residual stress becomes zero at around the strain point has resulted from the flow, the scale of which is larger than that of each step of the diffusion of ions. The behavior of $\mathrm{Si}-\mathrm{Al}-\mathrm{O}$ glass is assumed to be intermediate between $\mathrm{Si}-\mathrm{B}-\mathrm{Al}-\mathrm{O}$ and $\mathrm{Si}-\mathrm{Ca}-\mathrm{Na}-\mathrm{O}$ glasses.

\section{Conclusions}

Residual stress field around a Vickers diamond indentation was studied using three glasses with different strain points as specimens. The basis of the experimental technique is to use a small indentation to measure the residual stress at a specific point around a large indentation. Molecular dynamic simulation was also carried out to discuss the results. They are summarized as follows.

(1) Residual tensile and compressive stresses around a large indentation distributed to the distance of $400 \mu \mathrm{m}$ from the center of the indentation. The tensile and compressive stresses were about $10 \mathrm{MPa}$ and $-50 \mathrm{MPa} \sim-30 \mathrm{MPa}$, respectively, at a distance of $200 \mu \mathrm{m}$ from the indentation center.

(2) The residual stress decreased by heat treatment at temperatures as low as $300^{\circ} \mathrm{C}$ below strain points and became zero by keeping the indented specimen at the temperature close to the strain point of each glass, for $7.2 \mathrm{ks}$.

(3) The resistance to the decrease of the residual stress against temperature was in the order of $\mathrm{Si}-\mathrm{B}-\mathrm{Al}-\mathrm{O}$ $\left(T_{\mathrm{s}}=635^{\circ} \mathrm{C}\right)>\mathrm{Si}-\mathrm{Al}-\mathrm{O}\left(T_{\mathrm{s}}=570^{\circ} \mathrm{C}\right)>\mathrm{Si}-\mathrm{Ca}-\mathrm{Na}-\mathrm{O}\left(T_{\mathrm{s}}=\right.$ $\left.511^{\circ} \mathrm{C}\right)$.

The results were discussed based on the difference of the mobility of constituent ions and plastic flow of glasses.

\section{References}

1) Hirao, K., Ceramics Jaban, 36, 60-62 (2001).

2) Fujiwara, T., Ceramics Japan, 36, 76-79 (2001).

3) Lawn, B. R. and Swain, M. V., J. Mater. Sci., 10, 113-22 (1975).

4) Marshall, D. B. and Lawn, B. R., J. Am. Ceram. Soc., 60, 86-87 (1977).

5) Marshall, D. B. and Lawn, B. R., J. Mater. Sci., 14, 2001-12 
(1979).

6) Molis, S. E. and Clarke, D. R., J. Am. Ceram. Soc., 73, 3189-94 (1990).

7) Zeng, K. and Rowcliffe, D. J., J. Am. Ceram. Soc., 77, 524-30 (1994).

8) Zeng, K. and Rowcliffe, D. J., Acta metall. mater., 43, 1935-43 (1995).

9) Uchida, H., Kiguchi, T., Saiki, A., Wakiya, N., Ishizawa, N., Shinozaki, K. and Mizutani, N., J. Ceram. Soc. Japan., 107, 606-10 (1999).

10) Takeda, S. and Tari, I., J. Ceram. Soc. Japan, 107, 31-35 (1999).

11) Zimmermann, A., Fuller, E. R., Jr. and Rodel, J., J. Am. Ceram. Soc., 82, 3155-60 (1999).

12) Bisrat, Y. and Roberts, S. G., Mater. Sci. Eng., A288, 148-53
(2000).

13) Abe, H., Ikeda, K., Nakashima, H., Yoshida, F. and Koga, K., J. Ceram. Soc. Japan., 108, 416-19 (2000).

14) Lardner, T. J., Ritter, J. E., Shiao, M. L. and Lin, M. R., Int. J. Fract., 44, 133-43 (1990).

15) Malou, Z., Hamidouche, M., Madjoubi, M. A., Loucif, K., Osamani, H. and Bouaouadja, N., Glass Technol., 41, 55-58 (2000).

16) Anstis, G. R., Chantikul, P., Lawn, B. R. and Marshall, D. B., J. Am. Ceram. Soc., 64, 533-38 (1981).

17) Lawn, B. R., Evans, A. G. and Marshall, D. B., J. Am. Ceram. Soc., 63, 574-81 (1980).

18) Marsh, D. M., Proc. Roy. Soc. A., 279, 420-35 (1964).

19) Sehgal, J. and Ito, S., J. Am. Ceram. Soc., 81, 2485-88 (1998). 